\title{
A full-mouth rehabilitation using zirconia all-ceramic crowns: a case report
}

\author{
In-Seon Choi', Dong-Woon Kim', Jung-Jin Lee', Kyoung-A Kim², Jae-Min Seo* \\ 'Department of Prosthodontics, School of Dentistry and Institute of Oral Bio-Science, Chonbuk National University, Jeonju, \\ Republic of Korea \\ ${ }^{2}$ Department of Dentistry, School of Medicine, Eulji University, Daejeon, Republic of Korea
}

As patients' esthetic expectations increase, there is an increase in demand for cosmetic restorations of anterior and posterior teeth that resemble the natural tooth morphology and color. An example of high-strength all-ceramic systems is zirconia with CAD/CAM application. This case report describes a full-mouth rehabilitation using zirconia all-ceramic crowns supported by upper and lower implants and by a minimal increase in the occlusal vertical dimension in a patient with severe abrasion due to loss of posterior teeth. (J Dent Rehabil Appl Sci 2015;31(3):231-41)

Key words: zirconia; CAD/CAM; full mouth restoration; implants; vertical dimension

\begin{abstract}
서론
환자의 심미적인 요구가 높아짐에 따라 전치부 뿐만 아니라 구치부에서도 자연치와 유사한 형태와 색조를 가 지는 보철물을 이용한 치료가 이루어 지고 있다. ${ }^{1}$ 20세기 중반 개발된 금속도재관은 우수한 심미성을 가지는 도재 와 높은 강도를 지닌 금속의 장점을 결합하여 현재까지 치과 임상에 널리 활용되고 있다. 그러나 치은 퇴축으로 인한 금속 변연 노출, 금속-도재간 결합 실패, 금속 산화 물로 인한 치은 변색 등이 문제로 지적되어 왔다. ${ }^{2,3}$ 최근 치과 도재의 제조, 가공 기술이 발전하면서 심미적 한계 를 가진 금속도재 보철물이 완전 도재 보철물로 대체되 고 있다. 특히, $\mathrm{CAD} / \mathrm{CAM}$ 시스템을 이용한 보철물 제 작 방법이 보편화되면서 강도와 심미성이 우수한 지르코 니아 도재를 이용한 보철치료의 비중을 높아지고 있다. ${ }^{4,5}$ 현재 우수한 기계적 물성을 가지는 Yttrium-stabilized
\end{abstract}

*Correspondence to: Jae-Min Seo

Assistant Professor, Department of Prosthodontics, School of Dentistry and Institute of Oral Bio-Science, Chonbuk National University, 567, Baekje-daero, Deokjin-gu, Jeonju, 54896, Repulic of Korea

Tel: +82-63-250-2696, Fax: +82-63-250-2218, E-mail: jmseo@jbnu.ac.kr

Received: April 14, 2015/Last Revision: July 10, 2015/Accepted: July 27, 2015 tetragonal zirconia polycrystal (Y-TZP)는 단일 치아에서 전악에 이르는 다양한 범위의 고정성 보철 치료에 활용 된다. ${ }^{6}$

지르코니아는 현재 활용 가능한 도재 중 가장 높은 강 도와 파괴 인성을 지니고 있지만 불투명성이라는 심미적 인 한계도 가지고 있다. 이를 보완하기 위해 지르코니아 코어에 도재를 축성하는 방법을 사용하였다. 하지만 이 역시 약한 지르코니아-도재간 결합강도로 인해 축성 도 재의 박리 및 파절이 발생한다는 연구결과가 보고되고 있다. Guess 등 ${ }^{6}$ 은 단일 보철물에서 2 - 3년 동안 2 - 9\%, 고정성 국소의치에서 1 - 5년 동안 $3-36 \%$ 의 상부 축성 도재의 박리 또는 파절이 발생했다고 하였으며, Vult von Steyern 등 ${ }^{7}$ 은 24 개월 동안 $15 \%$ 의 상부 축성 도재의 박 리가 발생했다고 보고하였다. 이러한 문제를 해결하기 위해 강한 교합력이 가해지는 구치부에서는 단일구조 (monolithic) 지르코니아를 이용한 보철치료가 이루어지

Copyright@ 2015 The Korean Academy of Stomatognathic Function and Occlusion. (c) It is identical to Creative Commons Non-Commercial License. 
고 있다. 지르코니아 코어에 도재를 축성하지 않아 상부 도재의 박리 및 파절을 피할 수 있게 되었지만 여전히 자연스러운 치아 색조 재현이라는 과제는 남아있다. 최 근에는 기존 지르코니아 블록보다 투과성이 우수한 지 르코니아 블록이 개발되고 착색법을 이용해 지르코니아 자체에 자연스러운 치아 색을 입힐 수 있어 보다 심미적 으로 개선된 단일구조의 지르코니아 보철물이 제작되고 있다.

이 증례에서는 붕괴된 교합 및 상실된 치아를 회복시 키기 위해 수직고경을 변화시키고 임플란트 식립 및 지 르코니아 보철물을 이용한 전악 수복 치료를 실시하여 기능적, 심미적으로 만족할만한 결과를 얻었기에 이를 보고하고자 한다.

\section{증례 보고}

본 증례는 70세 여자 환자로 상악 전치부 보철물의 도 재 파절로 인한 심미적인 문제와 양측 하악 구치부 치 아 상실로 인한 저작 장애를 주소로 보철과에 내원하였
다. 전신적 병력으로 우측 의수를 사용 중이며 투약중인 약물은 없었다. 구내 소견에서 상악 전치부 보철물의 도 재 파절과 금속 변연 노출이 있었고 하악 치아에 중등도 이상의 마모가 관찰되며, 역 Spee 만곡(reverse curve of Spee)과 상악 구치부 치아의 정출로 인한 교합 부조화를 동반하였다(Fig. 1). 방사선 사진 상에서 \#25 치아의 이 차우식 및 하악 우측의 잔존 치근과 \#36 치아의 치주질 환으로 인한 심한 치조골 흡수 양상이 관찰되었다(Fig. 2). 턱관절 검사에서는 주의할만한 병적 소견은 관찰되 지 않았다.

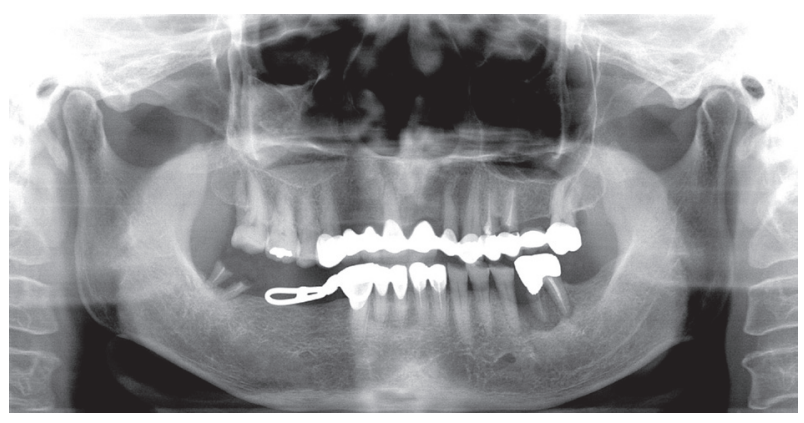

Fig. 2. Pre-treatment panoramic radiograph.

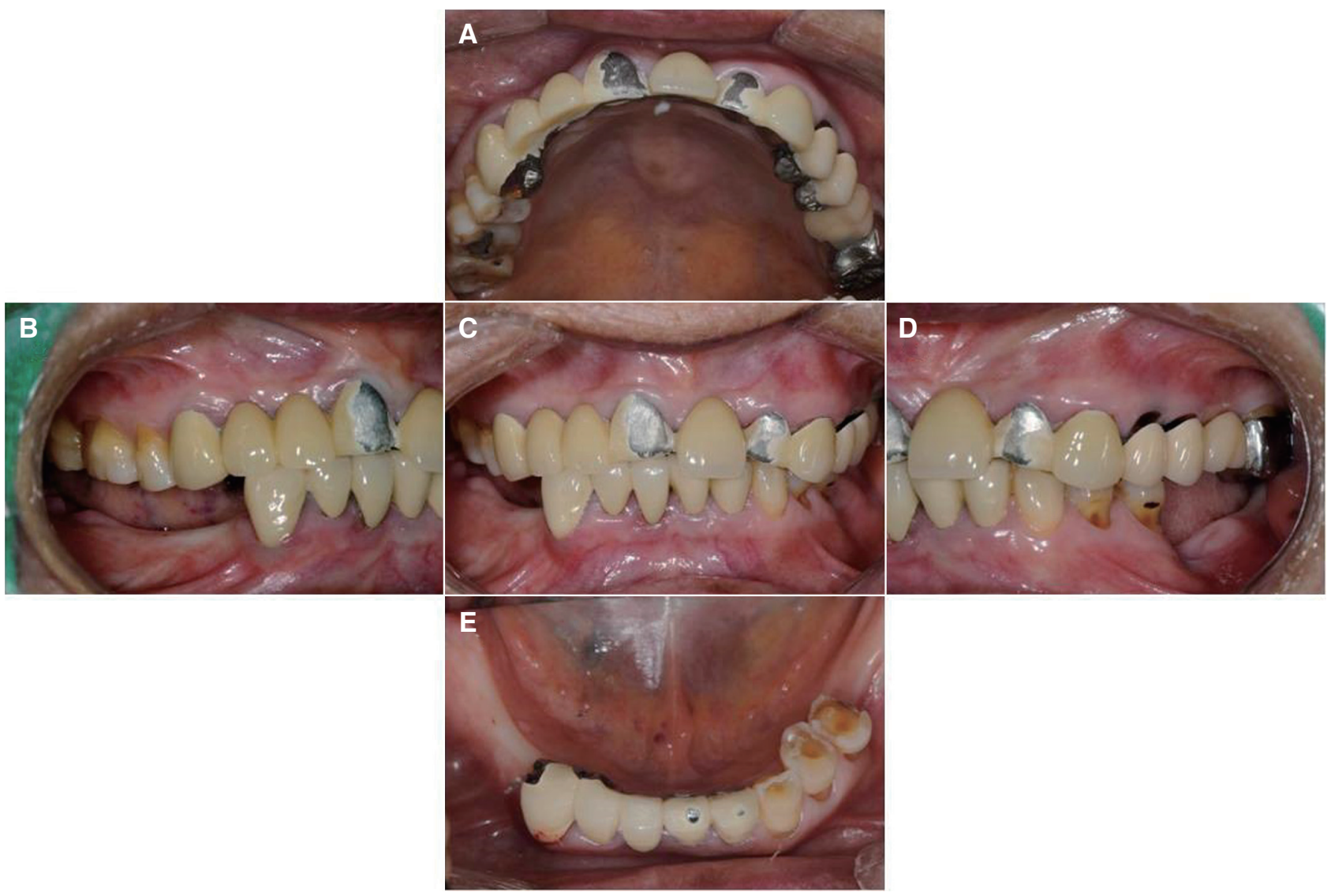

Fig. 1. Intra-oral status in the initial examination. (A) Maxillary occlusal view, (B) Right lateral view, (C) Frontal view at maximum inter-cuspal position (D) Left lateral view, (E) Mandibular occlusal view. 
환자는 심미성과 사용 편의를 위해 고정성 보철 치료 를 원하여, 상하악 무치악 부위 임플란트 식립을 포함한 고정성 보철물을 이용한 전악 수복을 계획하였다. 치료 전 환자교육을 실시하고 예후가 불량한 치아의 발치와 전반적인 치주치료를 진행하였다. \#36 치아는 치주농 양으로 인한 심한 치조골 파괴와 3 급 동요도를 보여 하 악 우측의 잔존 치근과 함께 발거하였다. 2주 후, 정확한 진단을 위해 예비인상을 채득하여 진단모형을 제작하 고 anterior jig와 교합제를 이용하여 중심위를 채득한 후 안궁이전하여 모형을 반조절성 교합기(Hanau modular articulator system 190, Whip Mix Co., Luisville, KY, USA)에 부착 하였다. 체크 바이트(check bite)법을 통해 과두 경사각을 결정하고 Hanau 공식을 이용하여 절치 유도각을 설정하였다. 안정시의 악간공극이 소구치 부 위에서 $6 \mathrm{~mm}$ 로 평균보다 크게 존재했고, Willis법을 이 용한 안면 계측에서 하안면 고경이 동공 구각부 거리보
다 $4 \mathrm{~mm}$ 적게 나타났다. 전치부의 임상적 치관 길이는 평균에 비해 $0.8-1.2 \mathrm{~mm}$ 정도 짧았다. 이를 종합하여 구치부 상실에 의해 수직고경이 감소한 것으로 진단하 였다. 평균 치관길이와 생리적 안정위의 교합면간 거리 평가 결과를 토대로 보철물 제작을 위한 최소한의 공간 확보를 위해 전치부 치아를 기준으로 $2 \mathrm{~mm}$ 수직고경 을 올리고 하악 전치의 평균 길이와 하악 구후융기 $2 / 3$ 를 기준으로 한 새로운 교합평면을 설정하여 진단 납형 을 제작하였다(Fig. 3). 전방 유도에 의해 구치가 이개됨 을 확인하고 측방운동시 우측은 견치 상실로 인해 군기 능교합으로, 좌측은 견치유도교합으로 교합양식을 부여 하였다(Fig. 4). 기존 보철물을 제거하고 초기 치아 삭제 후 진단 납형을 기준으로 미리 제작해 놓은 임시 보철물 을 장착하였다(Fig. 5). \#25 치아는 치근의 심한 이차 우 식으로 발거하였으며 \#33 치아의 우식 치료와 \#11, 23, $24,31,32,41$ 치아의 근관치료를 시행하였다.
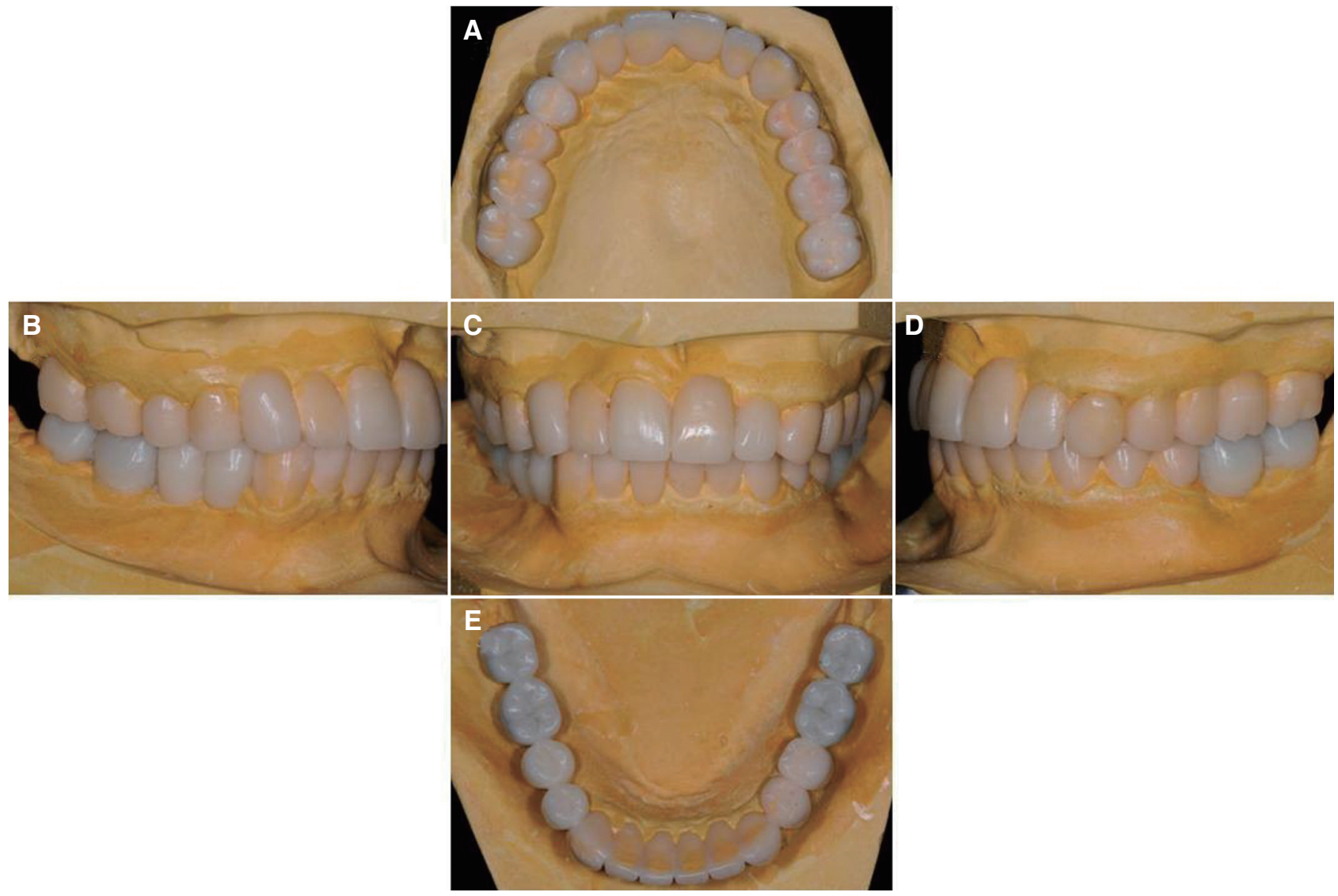

Fig. 3. Diagnostic wax-up model with increased vertical dimension. (A) Maxillary occlusal view, (B) Right lateral view, (C) Frontal view, (D) Left lateral view, (E) Mandibular occlusal view. 


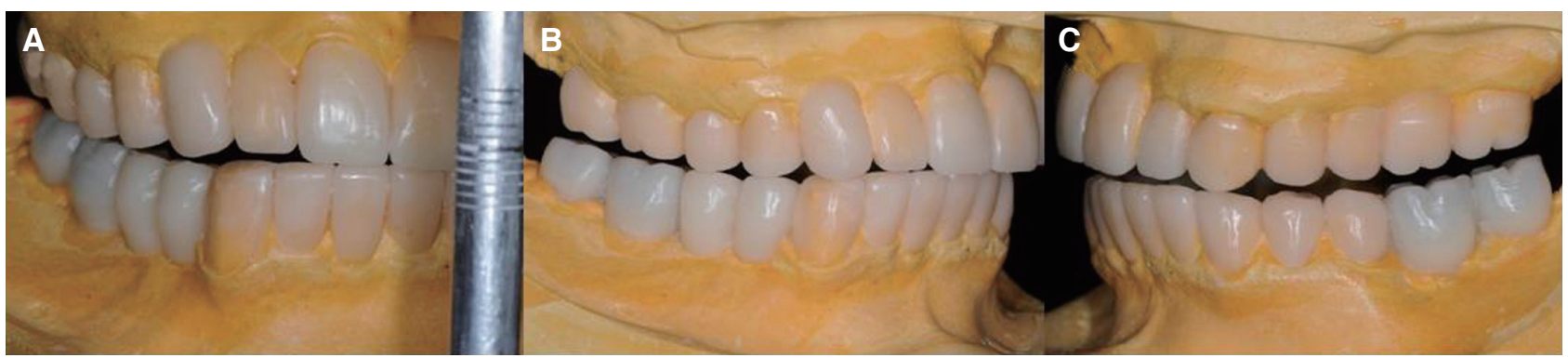

Fig. 4. Occlusion of eccentric movements. (A) Anterior movement, (B) Lateral movement- right side: group function, (C) Lateral movement- left side: canine guidance.

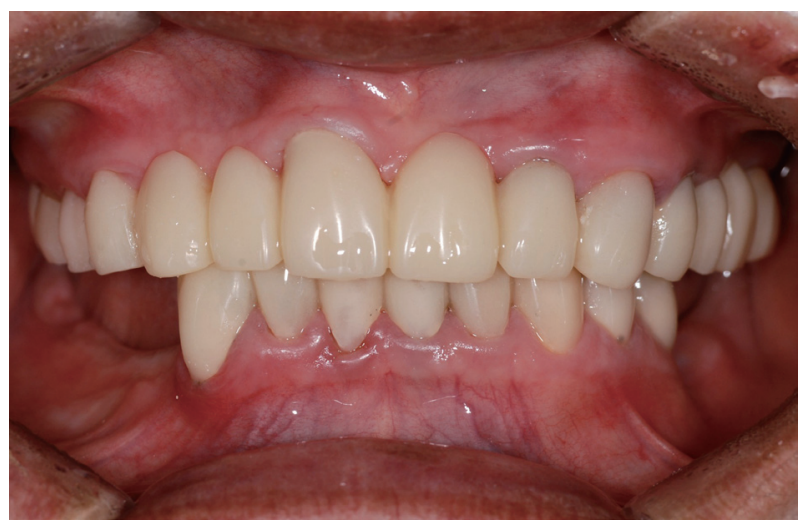

Fig. 5. 1st provisional restoration.

\#21, 22 무치악 부위는 경제적 사정으로 \#11, 23 치 아를 지대치로 하는 고정성 국소의치로 수복하기로 하 였고 다른 무치악 부위는 임플란트 식립을 위해 스텐 트 제작 후 컴퓨터 단층 촬영(Cone beam computedtomography; PSR9000N, Asahi Roentgen Co., Kyoto, Japan)하였다. 본 과에서 \#12, 13, 44, 46, 47 무치악 부 위에 5 개의 임플란트(Superline, Dentium Co., Seoul, Korea)를 식립하였다(Table 1). \#12, 13 무치악 부위는 치조골이 좁아 osteotome을 이용하여 직경 $3.5 \mathrm{~mm}$ 의
임플란트 2개를 식립한 후, \#44 - 47 부위의 치조제 평 탄화(flattening) 과정에서 얻은 자가골과 이종골(BioOss, Geistilich AG, Wolhusenm, Switzerland)을 1 : 1로 혼합하여 차단막(Bio-Gide, Geistilich AG)과 함께 골유 도재생술을 시행하였다. 3주 후, 상악 좌측 소구치부에 osteotome을 이용한 상악동 거상과 \#25, 26, 36, 37 무 치악 부위에 4개의 임플란트(Superline)를 식립하였다 (Table 1). 추가적으로 얇은 협측 치조골을 가진 \#25 부 위와 \#36 부위의 골결손부에 상기의 동일한 재료와 방 법으로 골유도재생술을 시행하였다. 임플란트 식립6개 월 후 상악 전치부 단층촬영을 통해 골유도재생술이 성 공적으로 이루어졌음을 확인하였고 2차 수술 후 인상채 득 하여 임시 보철물을 제작, 장착하였다. \#25, 26, 36, 37 식립 부위는 2차 수술과 동시에 임플란트 주위염, 치 은 퇴축에 대한 저항성, 용이한 치태관리, 심미적 개선 등에 중요한 역할을 하는 부착 치은 ${ }^{8,9}$ 을 형성해 주기 위 해 상악 우측 구개부를 공여부로 하는 유리치은이식을 시행하였다. 유리치은이식술 및 이차수술을 시행한 4 주 뒤 부착치은이 잘 형성된 것을 확인하고 \#12, 13, 25, $26,36,37,44,46,47$ 임플란트에 통법의 방법으로 제작 된 임플란트 고정성 임시 보철물을 연결하였다.

1 차 임시 보철물 장착 9 개월, 임플란트 식립 8 개월 후

Table 1. Diameter and length of installed implant fixture

\begin{tabular}{ccc}
\hline Location & Diameter $\times$ length & Corporation \\
\hline$\# 12,13$ & $3.5 \times 12 \mathrm{~mm}$ & \\
$\# 25,36,37,44,46,47$ & $4.5 \times 10 \mathrm{~mm}$ & Superline, Dentium Co., Seoul, Korea \\
$\# 26$ & $5.0 \times 10 \mathrm{~mm}$ & \\
\hline
\end{tabular}


에 2차 임시 보철물 및 최종 보철물을 위한 인상을 채 득하였다. 전치부 최종 인상 채득을 위해서는 \#12, 13 임플란트 임시 보철물을 임플란트 아날로그(DAN38, Dentium Co.)에 연결하고 퍼티(Aquasil Soft putty/ regular, Dentsply, Konstanz, Germany)로 인기한 후, 이 인상체와 일반적인 인상용 코핑(Impression coping pick-up, Dentium Co., Seoul, Korea) 사이에 유동성 레 진(UniFil Flow, GC, Tokyo, Japan)을 채워 임시 보철물 의 치경부출현각을 재현한 맞춤형 인상용 코핑을 제작 하였다(Fig. 6). 자연지대치를 최종 형성하고 임플란트 에 인상용 코핑을 연결하고 부가중합형 인상재(Aquasil ultra XLV, Monophase and Soft putty regular set, Dentsply, Konstanz, Germany)를 이용하여 최종 인상 채득하여 작업모형을 제작하였다(Fig. 7). 임플란트 바이 트 지그 및 기존 임시 보철물을 이용하여 교합관계를 채 득하고 안궁이전을 통해 작업모형을 교합기에 부착하였
다(Fig. 8). 2차 모형을 이용해 새로운 2차 임시 보철물을 제작하였으며 상악전치부와 임플란트 부위를 제외하고 는 모두 단일 치아 보철물로 제작하였다(Fig. 9).

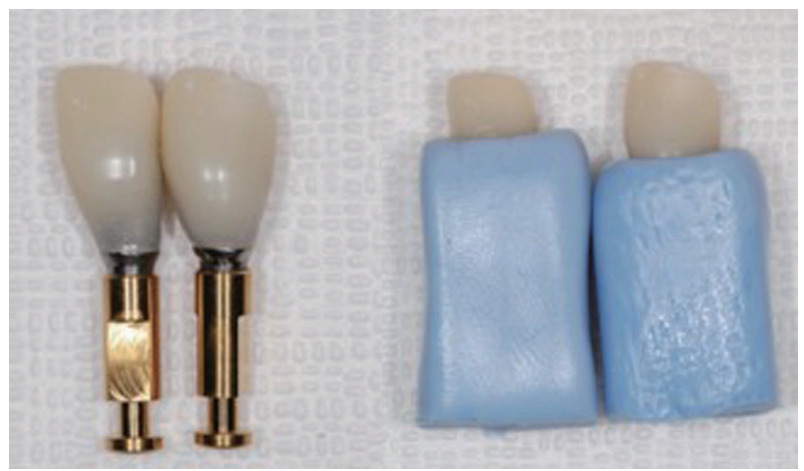

Fig. 6. Reproduction of the existing gingival contour with a putty for customized impression coping of \#12, 13 implant.

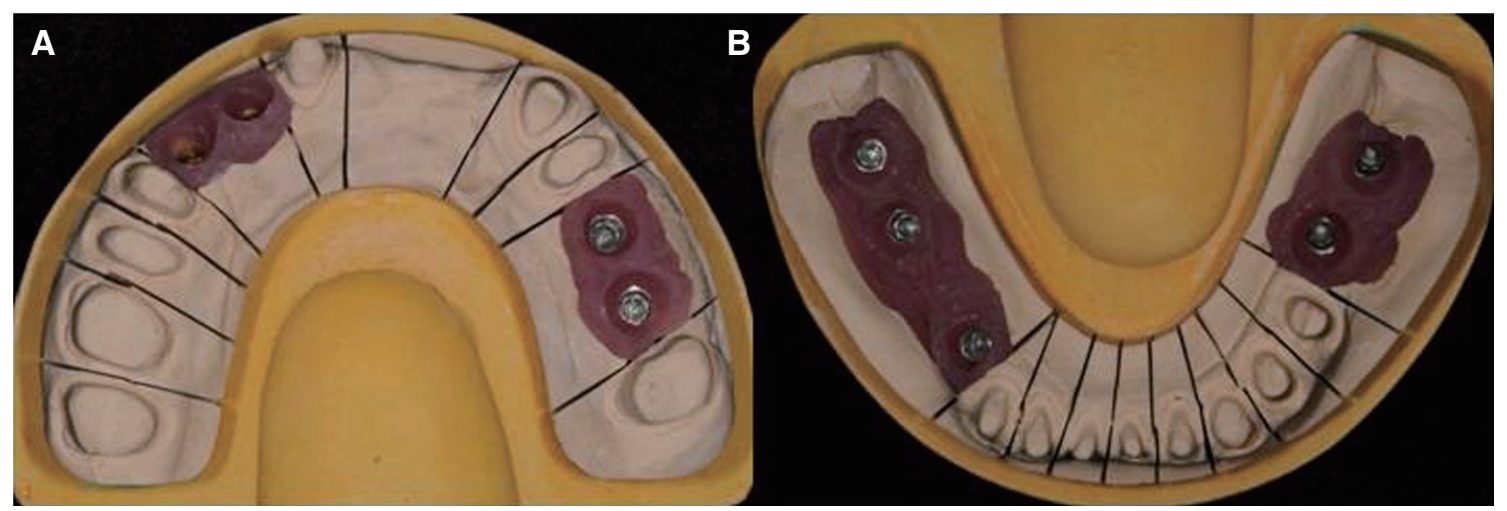

Fig. 7. Working cast for definitive prosthesis. (A) Maxillary occlusal view, (B) Mandibular occlusal view.

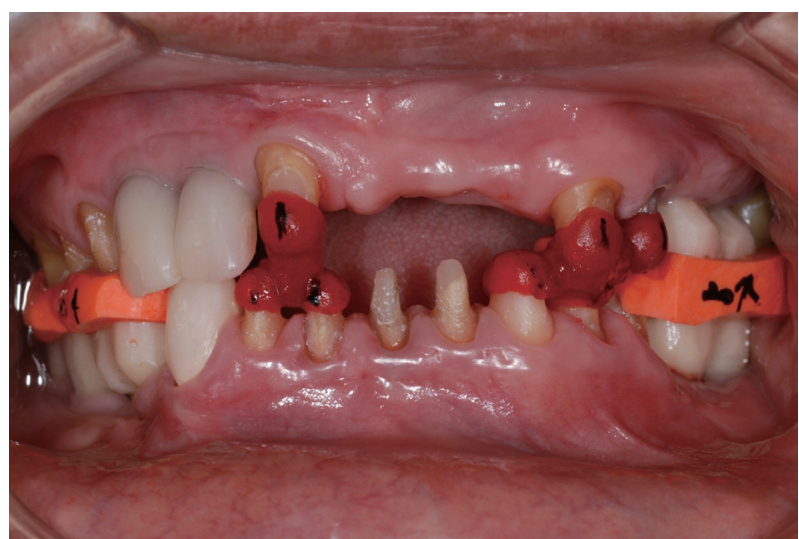

Fig. 8. Registration of inter-occlusal relationship with the provisional restoration.

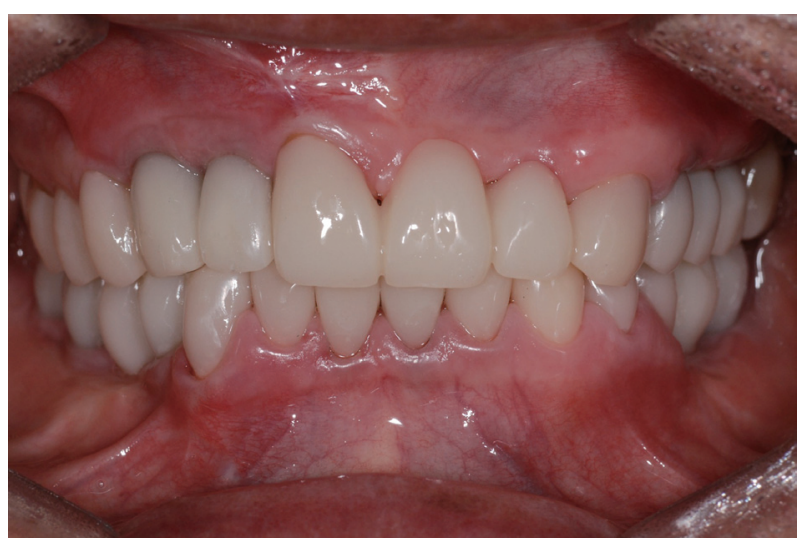

Fig. 9. Frontal view of the new provisional restoration. 
2차 임시 보철물 장착 8 주 동안, 환자는 새로운 임 시 보철물에 매우 만족해하였으며 심미적, 기능적 문제 가 발생하지 않아 최종 보철물 제작을 진행하기로 하였 다. 임시 보철물 장착 상태에서 비가역성 친수성 인상재 로 인상채득하고 모형을 제작한 후, 작업모형과 crossmounting하여 자가중협형 레진(Pattern resin LS, GC) 으로 맞춤형 전방유도장치를 제작하였다. 임플란트 지
대주는 $\mathrm{CAD} / \mathrm{CAM}$ 시스템을 이용한 맞춤형 지대주 로 제작하였는데 구치부는 티타늄 지대주(Myplant, Raphabio Co., Seoul, Korea)로, 전치부는 지르코니아 지대주(Zirconia Myplant, Raphabio Co.)로 제작하였다 (Fig. 10). 이후 지대주를 연결한 작업 모형에서 최종 보 철물의 형태대로 최종 외형 납형을 제작하였고(Fig. 11), 모형 스캐너(D700 3D scanner, 3shape, Copenhagen,

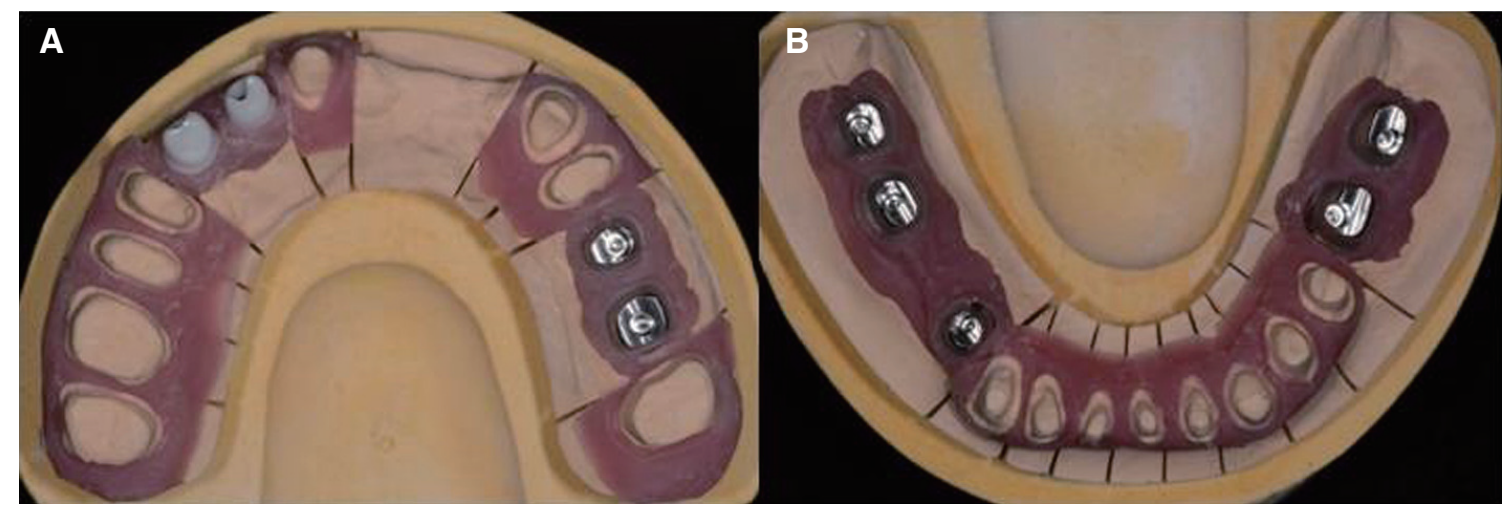

Fig. 10. Customized abutment for implant. (A) Maxillary occlusal view, (B) Mandibular occlusal view.

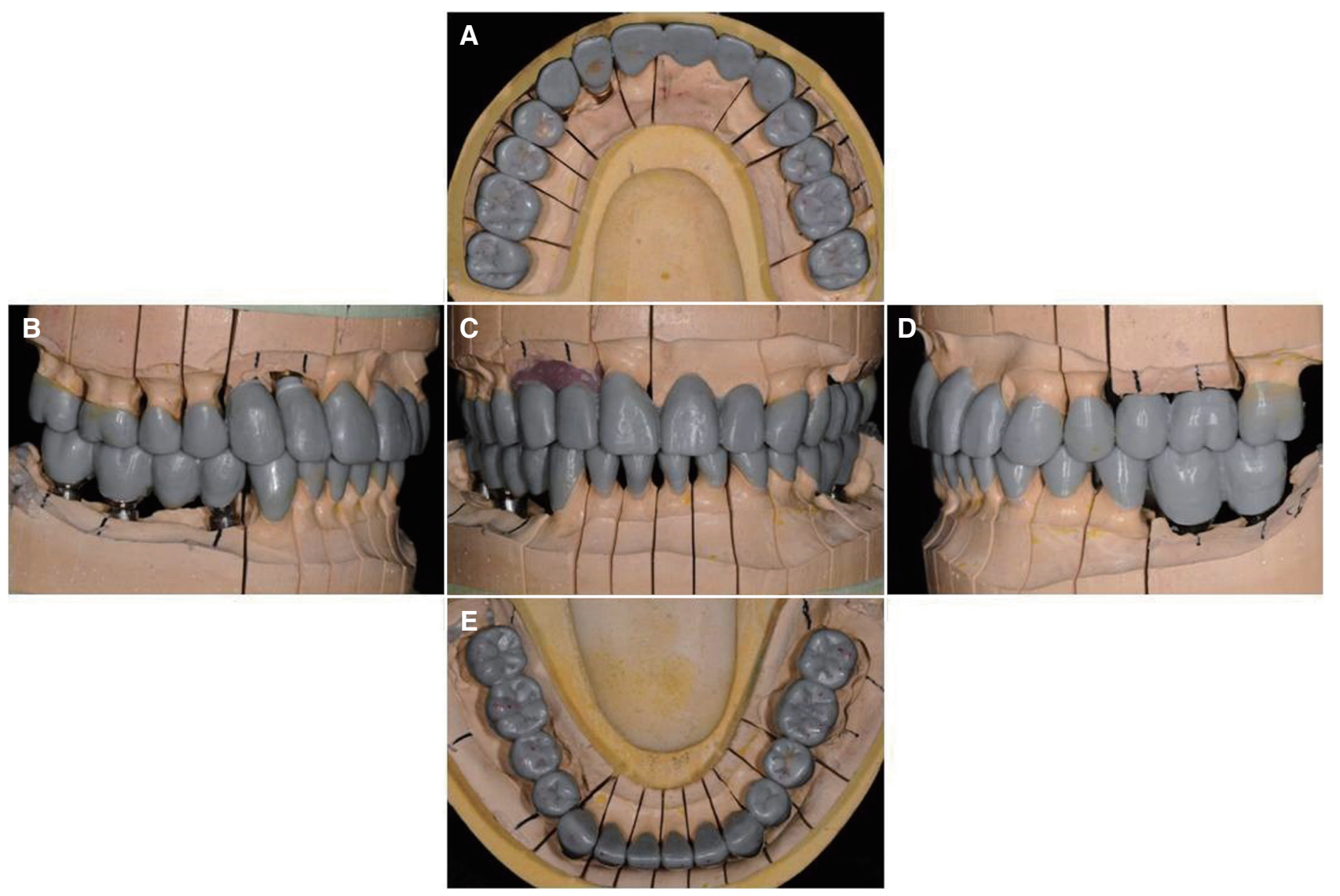

Fig. 11. Full contour wax-up for the definitive prosthesis. (A) Maxillary occlusal view, (B) Right lateral view, (C) Frontal view at maximum inter-cuspal position (D) Left lateral view, (E) Mandibular occlusal view. 
Denmark)를 이용하여 지대치와 납형 모형을 이중 스 캔 하여 구치부는 단일 지르코니아(Prettau, Zirkozahn, South Tyrol-Gais, Italy)로, 상, 하악 6 전치는 지르코니 아 코어(Prettau) 제작 후 도재(IPS e.max Ceram, Ivoclar Vivadent, Schaan, Germany)로 축성하여 최종 보철물을 제작하였다(Fig. 12).

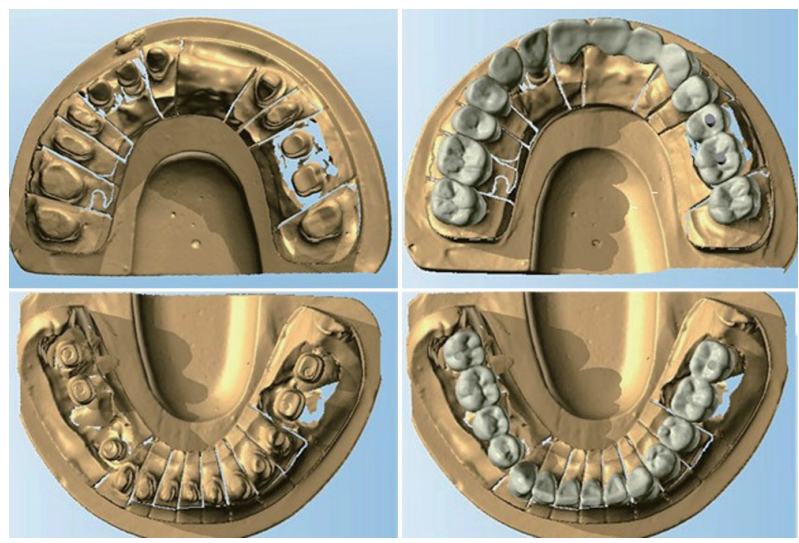

Fig. 12. Double scan images of working cast and wax-up model were superimposed.
자연치의 보철물은 시적, 조정 후, 내면을 tribochemical silica coating (Rocatec, 3M ESPE, Seefeld, Germany) 과 silane coupling agent (Rely X Ceramic Primer, 3M $\mathrm{ESPE}$ ) 처리한 후 이중 중합형 레진시멘트(Rely X Unicem, 3M ESPE)로 최종 합착하였다. 임플란트 보 철물은 임플란트 전용 레진시멘트(Premier implant cement, Premier dental products Co., Plymouth Meeting, $\mathrm{PA}, \mathrm{USA}$ )로 합착하였다(Fig. 13). 전방 운동시 양측 구 치가 이개되고 측방 운동시 우측은 군기능, 좌측은 견치 유도 교합이 형성됨을 확인하였다(Fig. 14). 교합분석장 비(T scan III, Tekscan Inc., Boston, MA, USA)를 이용 하여 최대 교두 감합시 우측 $48.3 \%$, 좌측 $51.7 \%$ 의 교합 력 분산과 안정적인 구치부 교합을 확인하였다(Fig. 15). Wood 등 ${ }^{10}$ 은 전악을 중심위 상태에서 수복하여도 다시 새로운 중심 교합위가 형성되므로 지속적인 교합조정이 필요하다고 하였다. 따라서 night-guard를 장착해주고 1 개월간 매주 내원하여 점검 및 교합조정을 시행하였고 추후 1 년간 3 개월마다 내원하여 교합 안정성을 확인하 였다. 최종 보철물 장착 3 년 후 내원시에도 양호한 구강 위생과 안정적인 교합 상태를 보였으며 환자는 심미적, 기능적으로 매우 만족해하였다(Fig. 16).

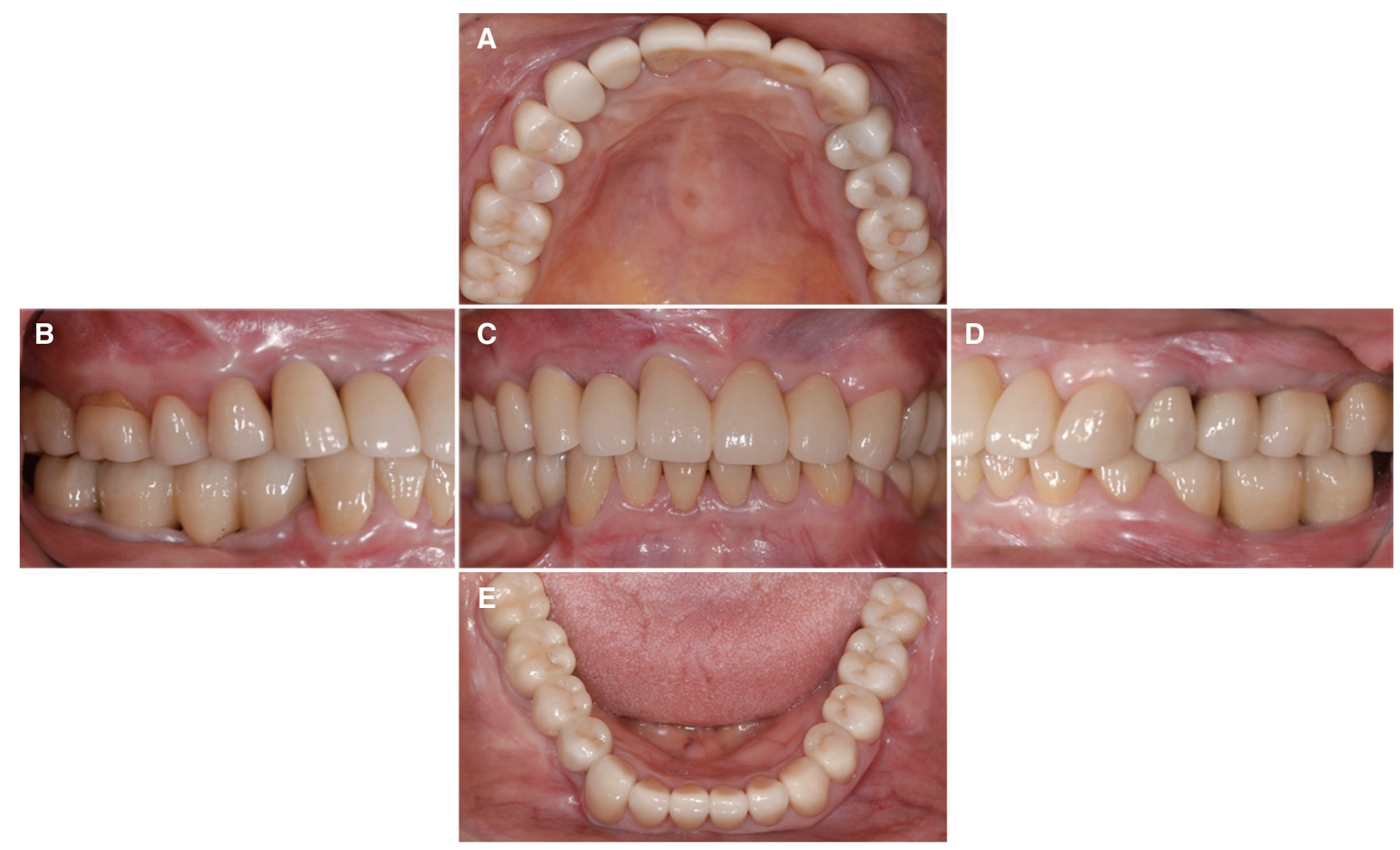

Fig. 13. Definitive prosthesis was delivered. Esthetics and functions were restored with the zirconia prosthesis. (A) Maxillary occlusal view, (B) Right lateral view, (C) Frontal view at maximum inter-cuspal position, (D) Left lateral view, (E) Mandibular occlusal view. 


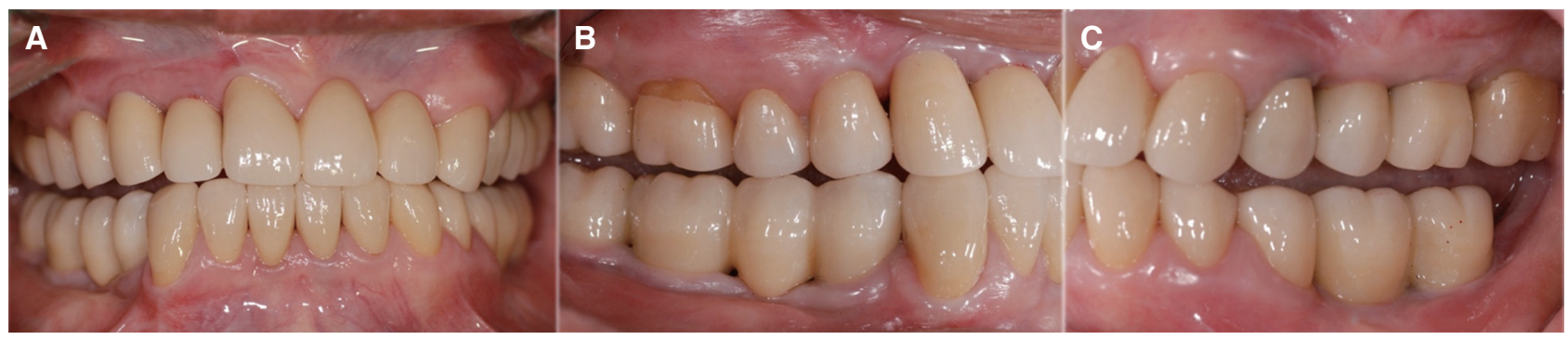

Fig. 14. Eccentric occlusion with definitive prosthesis. (A) Anterior movement: posterior teeth of both side were disoccluded, (B) Lateral movement - right side: group function, (C) Lateral movement - left side: canine guidance.

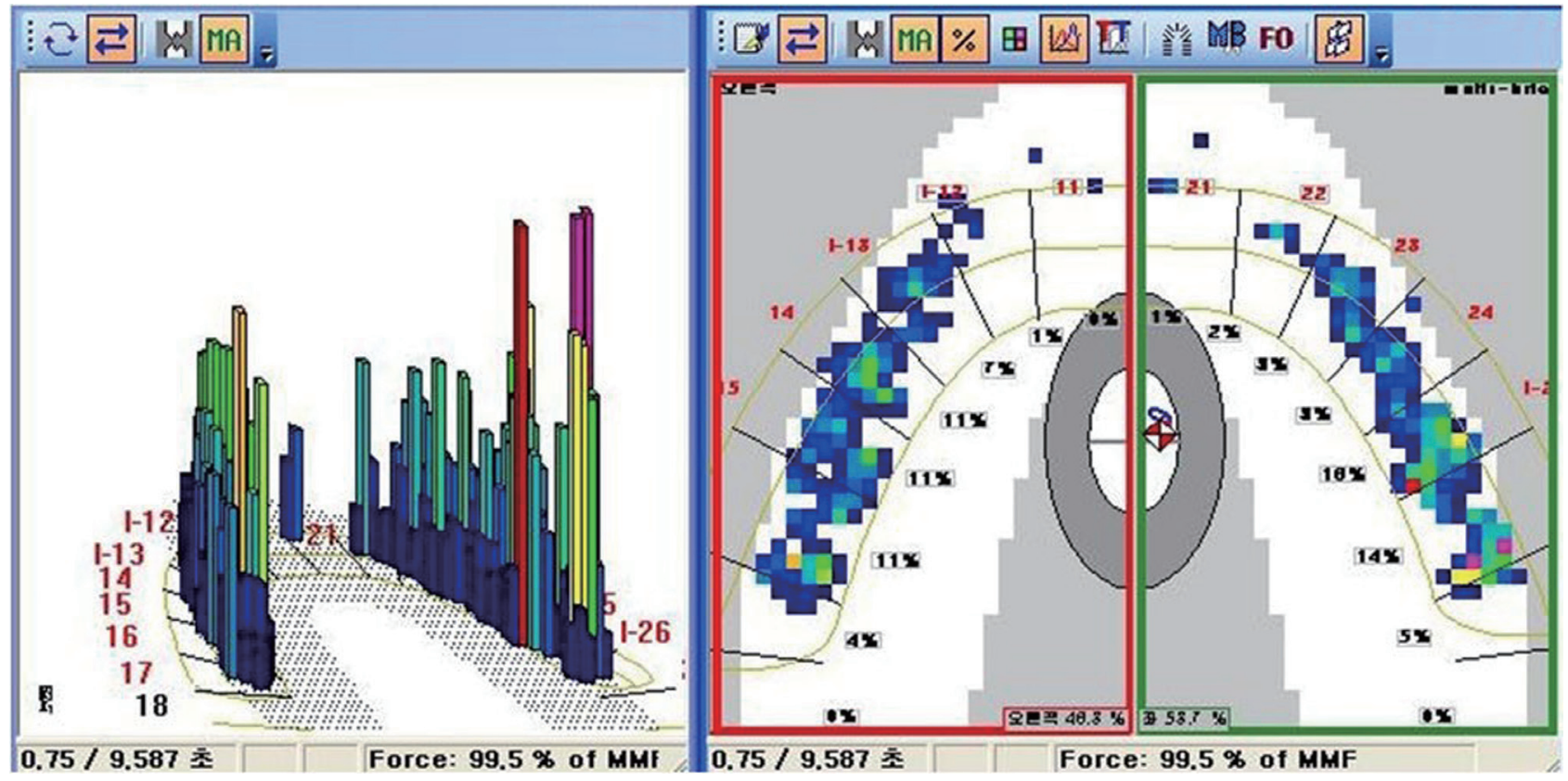

Fig. 15. Occlusal analysis using T scan III. Stable occlusion was present.

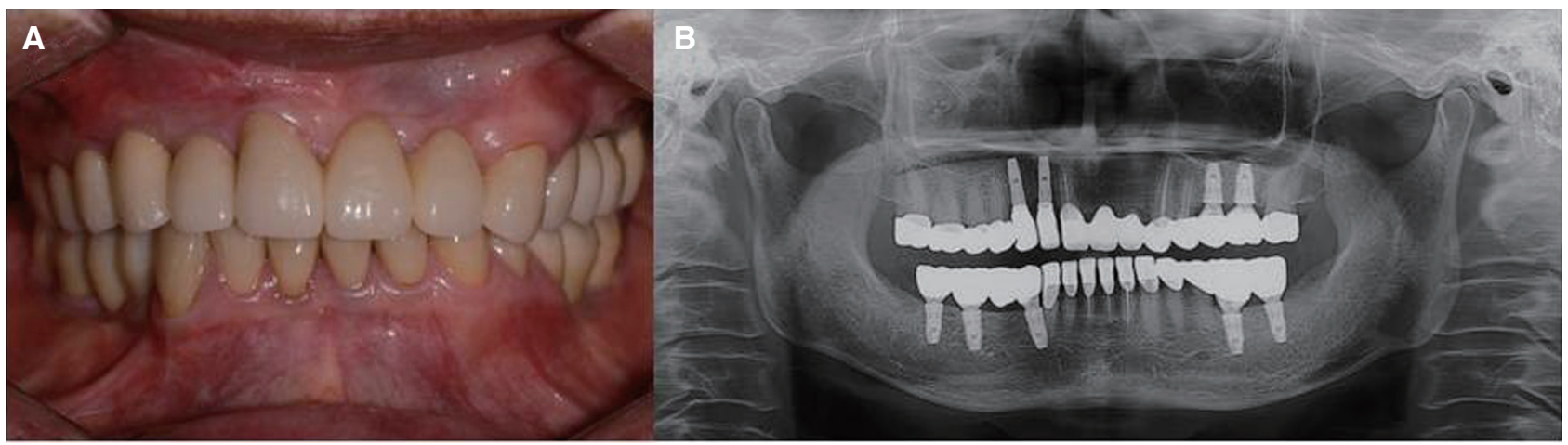

Fig. 16. Follow-up check after 3 years. (A) Stable occlusion and good oral hygiene were maintained, (B) Post-treatment panoramic radiograph. 


\section{고찰}

본 증례의 경우, 하악 구치부 상실로 인해 대합치가 정 출되고 전치를 이용한 저작으로 인해 하악 잔존치아의 병적 마모와 상악 보철물의 도재파절이 발생했을 것으 로 생각된다. 안정시의 악간 공극, 전치부 평균 길이, 안 모 계측, 구치부 보철 수복 공간 등을 분석하여 수직 고 경의 감소가 발생했다고 진단하여 상, 하악 임플란트 식 립과 교합 고경 증가를 동반한 전악 수복을 시행하였다. 수직고경 변화에 대한 여러 의견이 있지만 변화된 수직 고경이 환자가 적응할 수 있는 범위 내에 있고 임시 보 철물을 이용한 장기간 평가가 이루어진다면 예지성 있 는 보철치료를 위해 술자는 수직고경을 변화시킬 수 있 다. ${ }^{11,12}$

치료 과정에서 최종 보철물 제작 전 임시 보철물을 새 로 제작하였는데, 첫 번째 임시 보철물이 장기간 사용으 로 노후되었으며 2차 수술 후 추가적으로 만들어진 임 플란트 임시 보철물이 주변 자연치 임시 보철물과 완벽 하게 조합롭지 못했기 때문이다. 임시 보철물은 계획된 최종 보철물의 심미, 기능적 형태를 확인하고 수정할 수 있으며 변화된 수직고경에 대해 환자의 적응 여부를 판 단할 수 있는 단계이기 때문에 전악 수복과 같은 복잡한 치료에서 매우 중요한 역할을 한다.

지르코니아 보철물은 기존 금속 보철물이 가지는 강 도를 가짐과 동시에 도재의 심미성을 얻을 수 있다. 최 근 지르코니아의 임상 수명에 관한 연구에서 5년 생존 율은 $98 \%$ 로 보고되었다. ${ }^{13}$ 축성 도재의 파절은 $6-25 \%$ 로 비교적 높게 발생했다. ${ }^{14}$ 그래서 본 증례에서는 강한 교합력이 작용하는 구치부에는 단일구조 지르코니아 보 철물을 사용하였다. 장기간의 임상 결과가 부족하지만 $98 \%$ 의 3년 생존률을 보이고 있다. ${ }^{15}$

최근 투명도가 향상된 지르코니아 블록과 부위별로 색조를 재현할 수 있는 착색법이 개발되어 보다 심미적 인 구치부 보철물 제작이 가능하지만 완전 도재 수복물 보다는 여전히 불투명하다는 단점을 가져 본 증례의 전 치부 보철물 제작에는 지르코니아 코어에 도재를 축성 하는 방법을 선택하였다. 제작시 코어와 축성 도재의 열 팽창계수 차이가 크거나 냉각속도가 빠르면 지르코니 아-도재 계면 응력이 존재하게 되고, ${ }^{16}$ 상부 도재가 지르 코니아 코어에 완전히 지지되지 않거나 균일한 두께를 갖지 않으면 파절이 쉽게 발생할 수 있다. 이러한 재료 의 특성을 이해하고 적절한 형태를 갖도록 설계한다면
양호한 예후를 가질 수 있을 것으로 생각된다.

\section{결론}

본 증례는 구치부 상실로 교합이 붕괴되고 마모된 치 아를 가지는 환자에서 최소한의 수직고경을 변화시켜 임플란트 식립과 $\mathrm{CAD} / \mathrm{CAM}$ 시스템을 이용한 지르코니 아 고정성 보철물을 통해 전악 수복을 시행하였다. 이를 통해 성공적인 저작기능의 회복과 안정적인 교합, 심미 적인 만족을 얻었기에 이 증례를 보고하는 바이다.

\section{Orcid}

In-Seon Choi http://orcid.org/0000-0002-7544-076X

Dong-Woon Kim http://orcid.org/0000-0003-3609-6350

Jung-Jin Lee http://orcid.org/0000-0002-7381-5230

Kyoung-A Kim http://orcid.org/0000-0002-2923-5351

Jae-Min Seo http://orcid.org/0000-0001-5095-4046

\section{References}

1. Anusavice KJ. Recent developments in restorative dental ceramics. J Am Dent Assoc 1993;124:72-4, 76-8, 80-4.

2. Bagby M, Marshall SJ, Marshall GW Jr. Metal ceramic compatibility: a review of the literature. J Prosthet Dent 1990;63:21-5.

3. Campbell SD. A comparative strength study of metal ceramic and all-ceramic esthetic materials: modulus of rupture. J Prosthet Dent 1989;62:4769.

4. Kelly JR. Dental ceramics: current thinking and trends. Dent Clin North Am 2004;48:513-30.

5. McLaren EA. All-ceramic alternatives to conventional metal-ceramic restorations. Compend Contin Educ Dent 1998;19:307-8, 310, 312 passim; quiz 326.

6. Guess PC, Schultheis S, Bonfante EA, Coelho PG, Ferencz JL, Silva NR. All-ceramic systems: laboratory and clinical performance. Dent Clin North Am 2011;55:333-52.

7. Vult von Steyern P, Carlson P, Nilner K. All-ceramic fixed partial dentures designed according to 
the DC-Zirkon technique. A 2-year clinical study. J Oral Rehabil 2005;32:180-7.

8. Bouri A, Bissada N, Al-Zahrani MS, Faddoul F, Nouneh I. Width of keratinized gingiva and the health status of the supporting tissues around dental implants. Int J Oral Maxillofac Implants 2008; 23:323-6

9. Zigdon H, Machtei EE. The dimensions of keratinized mucosa around implants affect clinical and immunological parameters. Clin Oral Implants Res 2008;19:387-92.

10. Wood GN. Centric relation and the treatment position in rehabilitating occlusions: a physiologic approach. Part II: The treatment position. J Prosthet Dent 1988;60:15-8.

11. Fayz F, Eslami A. Determination of occlusal verti- cal dimension: a literature review. J Prosthet Dent 1988;59:321-3.

12. Abduo J. Safety of increasing vertical dimension of occlusion: a systematic review. Quintessence int 2012;43:369-80.

13. Ozkurt Z, Kazazoğlu E. Clinical success of zirconia in dental applications. J Prosthodont 2010;19:64-8.

14. Bachhav VC, Aras MA. Zirconia-based fixed partial dentures: a clinical review. Quintessence Int 2011; 42:173-82.

15. Al-Amleh B, Lyons K, Swain M. Clinical trials in zirconia: a systematic review. J Oral Rehabil 2010; 37:641-52.

16. Choi BK, Han JS, Yang JH, Lee JB, Kim SH. Shear bond strength of veneering porcelain to zirconia and metal cores. J Adv Prosthodont 2009;1:129-35. 


\section{지르코니아 전부 도재관을 이용한 구강 완전 회복 증례}

\section{최인선 ${ }^{1}$, 김동운 ${ }^{1}$, 이정진 ${ }^{1}$, 김경아 ${ }^{2}$, 서재민 ${ }^{1 *}$}

${ }^{1}$ 전북대학교 치의학전문대학원 치과보철학교실 및 구강생체과학연구소

${ }^{2}$ 을지대학교 의과대학 치과학교실

환자의 심미적 요구가 증가함에 따라 전치뿐만 아니라 구치부에서도 자연치아와 유사한 색조와 외형을 재현한 보철물 에 대한 필요성이 증가하고 있다. 단일 지르코니아와 $\mathrm{CAD} / \mathrm{CAM}$ 시스템을 통해 이러한 환자의 요구를 만족시키는 보 철물 제작이 가능해졌다. 본 증례는 70세 여자환자로 전치부 보철물이 깨져서 보기 싫고 하악 구치부가 없어서 저작이 불편하다는 주소로 내원하였다. 하악 구치의 상실로 교합평면이 붕괴되었으며 과도한 치아 마모 및 수직고경 상실이 관찰되어 치아 상실 부위에 임플란트를 식립하고 수직고경 증가와 함께 지르코니아 고정성 보철물을 이용한 전악 수복 치료를 진행하였다. 치료 후 3 년 간 이상적인 교합이 잘 유지되고 기능적, 심미적으로 만족한 결과를 얻었기에 이를 보 고하는 바이다.

(구강회복응용과학지 2015;31 (3):231-41)

주요어: 지르코니아; CAD/CAM; 전악수복; 임플란트; 수직고경 